\title{
STEROID SULFATASE DEFICIENCY IN JAPANESE PATIENTS : CHARACTERIZATION OF X-LINKED ICHTHYOSIS BY USING POLYMERASE CHAIN REACTION
}

\author{
Teruo Sugawara, ${ }^{1,2}$ Koichi Honke, ${ }^{1}$ Seiichirou Fujmoto, ${ }^{2}$ \\ and Akira MAKITA ${ }^{1}$ \\ ${ }^{1}$ Biochemistry Laboratory, Cancer Institute and ${ }^{2}$ Department of \\ Obstetrics and Gynecology, Hokkaido University School of Medicine, \\ Kita-ku, Sapporo 060, Japan
}

\begin{abstract}
Summary X-Linked ichthyosis (XLI) due to deficiency of steroid sulfatase (STS) of which gene consists of 10 exons is an inherited skin disorder. The gene, mRNA and protein of STS were examined in six Japanese patients with XLI. Neither the mRNA nor the enzyme protein was detected in a patient. The results of Southern analysis using STS cDNA as a probe indicated that all the patients examined exhibited large deletions of the STS gene. When exon 1 and the exon 10 of the STS gene were amplified by polymerase chain reaction using patients' genomic DNA as templates, no product was detected in all the patients examined. These observations suggest that most XLI in Japanese patients is caused by an extensive deletion of the STS gene as was demonstrated in Caucasian patients. The PCR method in the present study is useful for the diagnosis of XLI in prenatal and postnatal subjects.
\end{abstract}

Key Words X-linked ichthyosis, STS, PCR, steroid sulfatase deficiency

\section{INTRODUCTION}

Steroid sulfatase (STS) [EC 3.1.6.2] is a microsomal enzyme and presents ubiquitously in mammalian tissues, especially in placenta (Warren and French, 1965). STS desulfates a number of 3- $\beta$-hydroxysteroid sulfates, converting inactive steroid hormone to the active form (Adessi et al., 1982). X-linked ichthyosis (XLI) is an inherited skin disorder due to the deficiency of the STS activity. It affects between 1 in 2,000 and 1 in 6,000 males according to the geographic locations and racial and ethnic background. A deficiency of placental STS results in a low estriol level in the urine and plasma of the mother of the affected fetus. XLI has been

Received April 9, 1993; Revised version accepted July 23, 1993. 
diagnosed by assaying STS activity in placenta or lymphocytes of the patient after birth (Shapiro 1989, for a review). The STS gene was cloned (Yen et al., 1987) and it was found that most patients with XLI in U.S.A. and Europe have large deletions of the STS gene (Shapiro et al., 1989). In this study, we examined the sulfatase gene and the enzyme protein of Japanese patients with XLI.

\section{MATERIALS AND METHODS}

Patients and human materials. Six Japanese patients were diagnosed clinically or enzymatically as X-linked ichthyosis. Fibroblasts in primary culture were obtained from skin of a patient (case 1) and normal male. An endometrial carcinoma cell line (Ishikawa cells) was from Dr. Nishida (Kitasato University School of Medicine).

Reagents. $\quad\left[7-{ }^{3} \mathrm{H}\right]$ Dehydroepiandrosterone sulfate (DHAS, $25 \mathrm{Ci} / \mathrm{mmol}$ ) was purchased from New England Nuclear; $\left[\alpha^{32} \mathrm{P}\right] 2^{\prime}$-deoxy cytidine 5 -triphosphate (dCTP) $(3,000 \mathrm{Ci} / \mathrm{mmol})$ from Amersham; a DNA amplification reagent kit and a random primer DNA labeling kit from Takara (Tokyo); murine Moloney leukemia virus (M-MLV) reverse transcriptase from BRL; and an oligo(dT)15-primer from Promega. The other reagents were of the analytical grade. A full-length cDNA of STS was generously gifted from Dr. Shapiro (Howard Hughes Medical Institute Research Laboratories). STS was purified from human placenta as described previously (Sugawara et al., 1991), and rabbit anti-STS IgG was prepared.

Assay of steroid sulfatase activity. STS activity was assayed according to Epstein and Leventhal (1981) with a slight modification. The reaction mixture contained $20 \mathrm{~mm}$ Tris- $\mathrm{HCl} \mathrm{pH} 8.0,2 \mu \mathrm{mol}$ DHAS $(10,000 \mathrm{cpm}), 1 \%$ Triton-X-100 and enzyme source. Following incubation at $37^{\circ} \mathrm{C}$ for $1 \mathrm{~h}$, the reaction was terminated by adding $0.6 \mathrm{ml}$ of benzene on ice. One unit of activity was defined as the amount of enzyme which catalyzes the hydrolysis of $1 \mathrm{nmol}$ of substrate per hour.

Western blotting of steroid sulfatase. The $20 \%$ homogenate of placenta was electrophoresed in $10 \%$ polyacrylamide gel in the presence of sodium dodecyl sulfate and then transferred to a nitrocellulose membrane, followed by staining with rabbit anti-STS antibody.

Reverse transcription of steroid sulfatase $m R N A$ and amplification. Total RNA was isolated from XLI fibroblasts by the guanidium $\mathrm{SCN}-\mathrm{CsCl}$ gradient method (Chomcznski and Sacchi, 1987). Complementary DNA synthesis was carried out at $37^{\circ} \mathrm{C}$ for $60 \mathrm{~min}$ using $150 \mathrm{pmol}$ of oligo dT as a primer, $10 \mu \mathrm{g}$ total RNA and 200 units of M-MLV reverse transcriptase in $20 \mu$ l reaction mixture containing $100 \mathrm{~mm}$ Tris- $\mathrm{HCl} \mathrm{pH} 8.2,80 \mathrm{~mm} \mathrm{KCl}, 10 \mathrm{~mm} \mathrm{MgCl}_{2}, 10 \mathrm{~mm}$ dithiothreitol and $1 \mathrm{~mm}$ each of dATP, dCTP, dGTP, and dTTP. The polymerase chain reaction (PCR) was carried out essentially as described previously (Saiki et al., 1988) using the first strand cDNA as a template. One-fourth of the synthesized cDNA was 
mixed with 1 unit of Taq polymerase and 10 pmol each of primers, R1 and R2 (Fig. 1) in a total volume of $50 \mu \mathrm{l}$ containing $0.2 \mathrm{~mm}$ each of dATP, dTTP, dCTP, and dGTP, $50 \mathrm{mM} \mathrm{KCl}, 1.5 \mathrm{mM} \mathrm{MgCl}_{2}$ and $10 \mathrm{~mm}$ Tris- $\mathrm{HCl}, \mathrm{pH}$ 8.3. The reaction was subjected to 30 cycles of denaturation at $94^{\circ} \mathrm{C}$ for $1 \mathrm{~min}$, annealing at $59^{\circ} \mathrm{C}$ for $2 \mathrm{~min}$ and extension at $72^{\circ} \mathrm{C}$ for $3 \mathrm{~min}$. The products were electrophoresed on a $1 \%$ agarose gel and detected with ethidium bromide.

Isolation of DNA and Southern blotting. High molecular weight DNA was isolated from human leukocytes or cultured fibroblasts according to the previous method (Blin and Stafford, 1976) and digested with EcoRI. The DNA fragments were subjected to electrophoresis on a $0.7 \%$ agarose gel, transferred to a nylon membrane and hybridized with a full length cDNA of STS that had been labeled with $\left[\alpha_{-}{ }^{32} \mathrm{P}\right] \mathrm{dCTP}$ by random primer labeling method (Feinberg and Vogelstein, 1983). The hybridized membrane was washed at $60^{\circ} \mathrm{C}$ with $0.2 \times \mathrm{SSC}$ containing $0.1 \%$ sodium dodecyl sulfate (SDS).

Amplification of steroid sulfatase exons. We designed two sets of oligonucleotide primers D1 and D2 for the amplification of exon 1, and D5 and D6 for exon 10 (Fig. 1). PCR was performed using these primers and $1 \mu \mathrm{g}$ of genomic DNA as a template in 30 cycles as above. The products were electrophoresed on a $1 \%$ agarose gel and detected with ethidium bromide. The nucleotide sequences of the amplified DNA products exons 1 and 10 using genomic DNA from a normal subject were examined by the dideoxy chain-termination method (Sanger et al., 1977).

\section{RESULTS AND DISCUSSION}

Steroid sulfatase protein and $m R N A$ of a $X$-linked ichthyosis patient (case 1)

In a pregnant women whose urine contained a low amount of estriol $(<5 \mu \mathrm{g} /$ $\mathrm{ml}$ ), her fetus (case 1) was suspected to have XLI. At delivery, the STS activity of the placenta was significantly low $(0.01 \mathrm{unit} / \mathrm{mg}$ protein) compared to normal

\begin{tabular}{|c|c|c|c|c|c|c|c|c|c|}
\hline 1 & 2 & 3 & 4 & 5 & 6 & 7 & 8 & 9 & 10 \\
\hline D1 D2 & R3 & R4 & D5 & D6 \\
(214bp) & & & (275 bp) & (414bp)
\end{tabular}

Fig. 1. Exons of STS enzyme and sites of primers for PCR. Primers synthesized by a DNA synthesizer (ABI, type 380B-02) are: D1 (5'-GGGAATTCAAGCCTCCAGCAGCTGA3', sense), and D2 (5'-CTTAAAGGCATCTCCAGCTT-3', antisense) for the amplification of exon 1; D5 (5'-GGGAATTCTGGTGAGCTTTGCCCACAT-3', sense) and D6 (5'-ACATCCATCTGGAAGGCCTT-3', antisense) for exon 10; R3 (5'-GAACACTGAGACTCCGTTCCT-3', sense) and R4 (5'-CTTTATAGATCCCATTACTTCCGCC$3^{\prime}$, antisense) for exons 6 and 7. The nucleotides synthesized with primers R3 and R4 include an intron present between exons 6 and 7. 
values (13.5 \pm 2.5 units/mg protein) and the baby was diagnosed enzymatically as XLI. Actually, ichthyosis appeared three months after birth. In order to examine whether the low enzyme activity in the placenta is based on a deficient amount of the enzyme protein, Western blotting was performed with anti-STS antibody. In the immunoblotting analysis, no cross-reacting peptide with the anti-STS antibody was detected in the patient's placenta although a single band was observed corresponding to STS in a normal subject (Fig. 2). This result suggests that the low STS activity in the patient's placenta resulted from a defect of the enzyme protein rather than formation of an inactive enzyme protein.

To elucidate the cause of the defect, we examined mRNA of STS from the patient's and control fibroblasts. Complementary DNAs synthesized from cellular RNAs were amplified by PCR using primers R3 and R4 (Fig. 1) and subjected to electrophoresis (Fig. 3). The expected product of $275 \mathrm{bp}$ was obtained in a normal male cells and the Ishikawa cells. However, the XLI patient did not give the STS gene fragment (Fig. 3). These observations indicate that the patient cannot synthesize functional or immunologically recognizable STS protein.

\section{Southern blot analysis of the steroid sulfatase gene from X-linked ichthyosis patients}

To investigate if the defect of the STS mRNA results from the deletion of the STS gene, Southern blotting using EcoRI digests of cellular DNA from six XLI patients and full-length STS cDNA as a probe. As shown in Fig. 4, normal male included bands of $20,15,10,9.0,6.1,4.6,4.2,3.1,2.6$, and $1.5 \mathrm{kbp}$ as reported previously (Shapiro et al., 1989). Normal female included the same bands as normal male except that the 20 and $1.5 \mathrm{kbp}$ bands were lacking. Both the 20 and $1.5 \mathrm{kbp}$ fragments are known to be derived from the $Y$ locus and pseudogene of the STS gene (Yen et al., 1988). All the six patients examined had only the 20, 9.0, 3.6, 2.2 , and $1.5 \mathrm{kbp}$ fragments lacking $15,10,6.1,4.6,4.2,3.1$, and 2.6 fragments. Although the previous report (Shapiro et al., 1989) has not mentioned about the bands of 9.0, 3.6, and $2.2 \mathrm{kbp}$, they were also observed in normal subjects and presumed to be DNA fragments possessing sequences similar to but unrelating to the STS gene. These results indicate that the six XLI patients are totally deleted of the STS gene. Most patients with XLI in USA and Europe had large deletions of the STS gene (Yen et al., 1987; Ballabio et al., 1989). Thus, the genetic subtype of XLI which results from an extensive deletion of exons over the STS gene appears to bear the most frequent incidence of the XLI syndrome irrespective of ethnic differences. Determination of the actual feature of the deletion should be resolved. Some patients had a partial deletion or a point mutation of the STS gene (Basler et al., 1992).

\section{Diagnostic application of $P C R$ analysis for $X L I$}

Prenatal diagnosis of XLI is currently made by assaying STS activity in cultured amniotic cells. The STS assay requires cell amount enough to measure the 


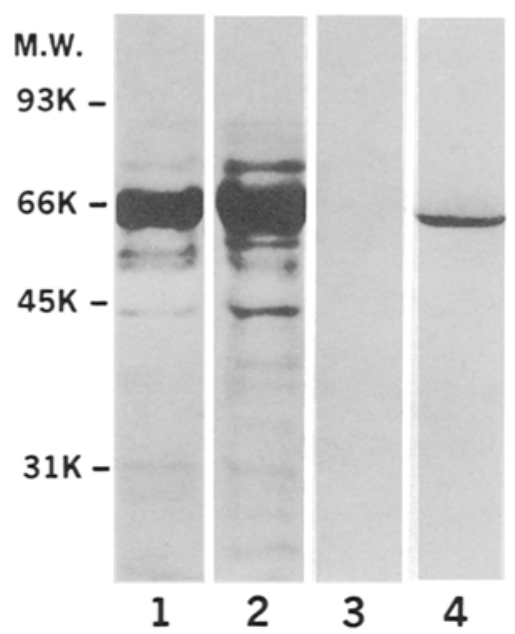

Fig. 2. Western blotting of steroid sulfatase. Whole homogenates of placenta from a case 1 patient $(10 \mu \mathrm{g}$ protein) and a normal subject (10 $\mu \mathrm{g}$ protein) were electrophoresed and immunoblotted using polyclonal anti-STS antibody. Lanes 1 and 3 , STS deficient patients, and lanes 2 and 4, normal controls stained with amidoblack (lanes 1 and 2) or immunostained (lanes 3 and 4).

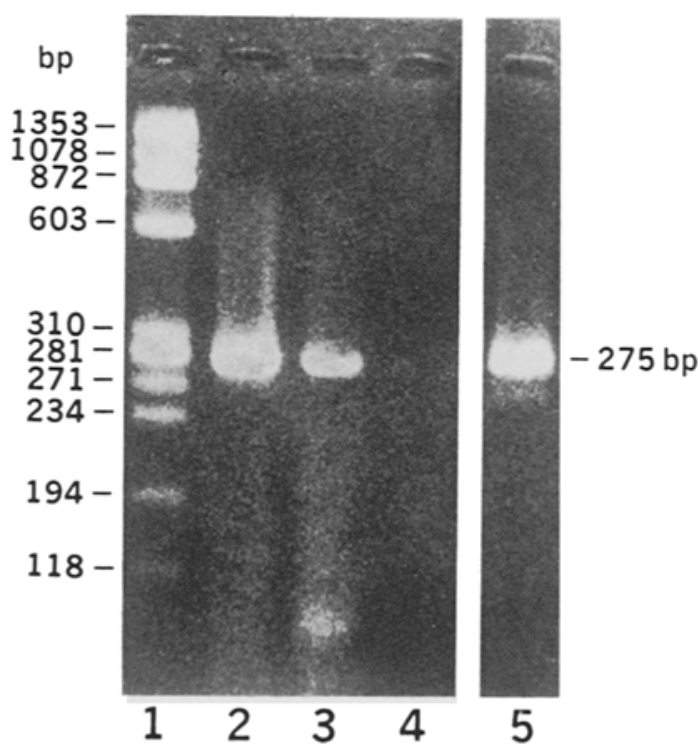

Fig. 3. Analysis of reverse-transcripts of STS mRNA. Complementary DNAs synthesized from total RNAs of a XLI patient and controls were amplified using R3 and R4 as primers by PCR method and subjected to electrophoresis detecting with ethidium bromide ( $275 \mathrm{bp}$ ). Lanes 1 , molecular weight standards; 2 , normal male fibroblasts; 3 , Ishikawa cells; 4, XLI fibroblasts (case 1); and 5, a positive control which was synthesized using full length cDNA as a template. 


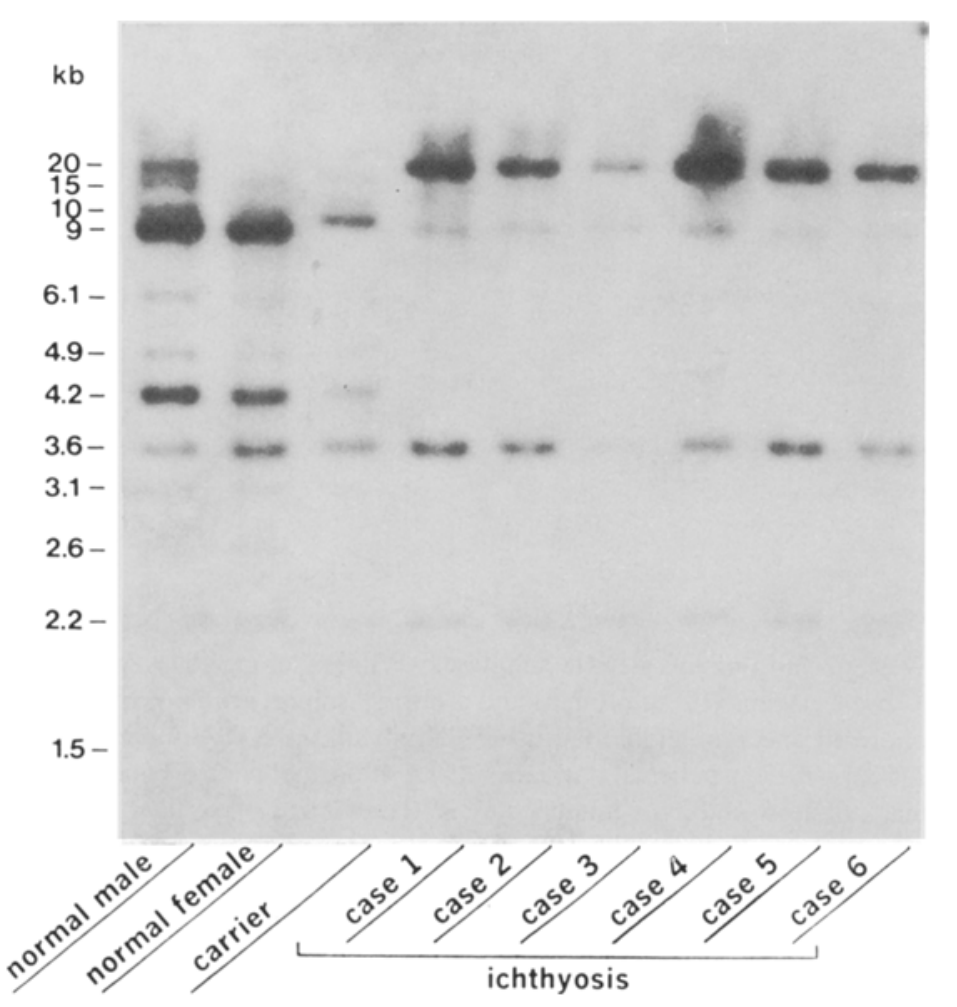

Fig. 4. Southern blot of STS gene from XLI patients. Cellular DNAs $(10 \mu \mathrm{g}$ each) from male, female, and six XLI patients were digested with EcoRI and subjected to Southern blot using STS cDNA as a probe, as described under MATERIALS AND METHODS. Carrier represents the mother of case 1.

activity and a radioactive compound as a substrate of which practice should be done in a special facility. The present and previous (Shapiro et al., 1989) results on the Southern blot analysis of STS gene let us propose a simple, prenatal diagnosis of XLI. Because most XLI patients had entire deletion of the STS gene, a PCR analysis of the terminal regions of the gene is effective to detect the deletion. Two polynucleotides corresponding to exon $1(214 \mathrm{bp})$ and $10(414 \mathrm{bp})$ which were prepared with 2 pairs of primers, D1-D2 and D4-D5, respectively, using cellular DNA from normal male and female by PCR, cover the entire STS gene. By sequence analysis, both the probes had the nucleotide sequences corresponding to the STS gene in present studies. However, these STS fragments could not be amplified from the six ichthyosis patients as was expected (Fig. 5). These results provide that the present PCR analysis is useful for the diagnosis of the disease in fetus. The amount of amniotic cells obtained by one amniocentesis is possible to prepare the template cellular DNA in the PCR amplification. 


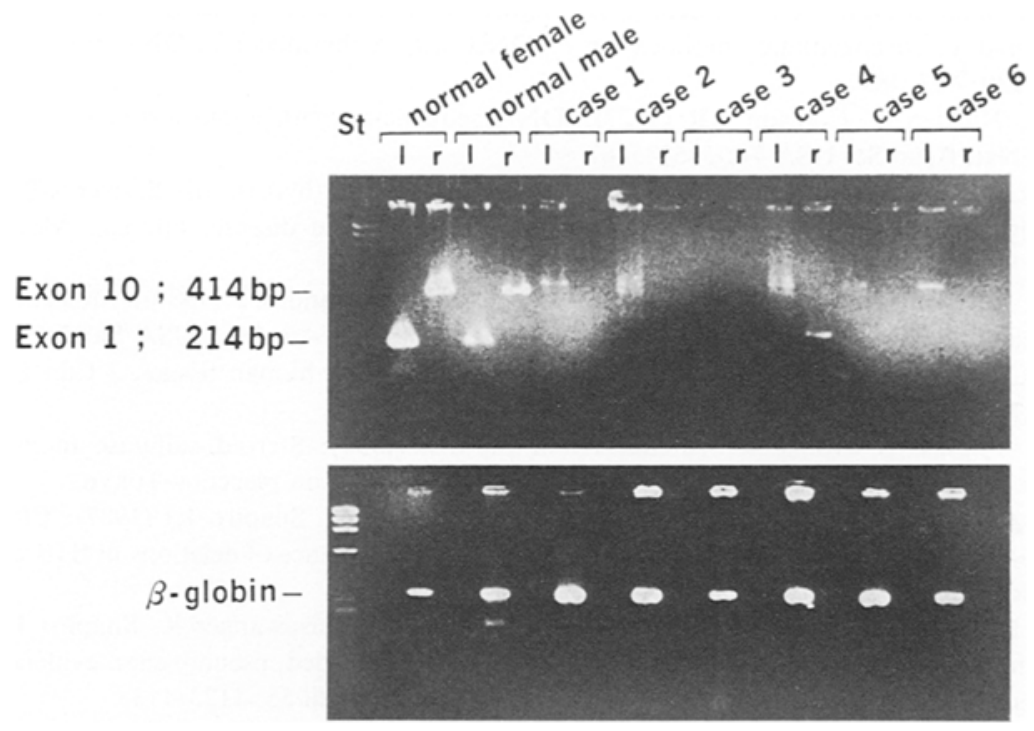

Fig. 5. PCR analysis of STS exon 1 and 10. Upper panel, two DNA fragments were amplified by PCR method using genomic DNAs from peripheral blood lymphocytes of XLI patients and normal controls as templates and two pairs of primers, D1-D2 (exon 1) and D4-D5 (exon 10), and electrophoresed on two lanes each, detecting with ethidium bromide. Lower panel, beta-globin nucleotides were amplified using the same DNAs as above and beta-globin primers, and for confirmation of polynucleotide synthesis.

Acknowledgments The authors thanks Dr. L.J. Shapiro (Howard Hughes Medical Institute Research Laboratories) for supplying cDNA of steroid sulfatase.

\section{REFERENCES}

Adessi GL, Nhuan TQ, Vingler P (1982): In vivo and in vitro metabolism of estrone and estradiol-17 and their 3-sulfates in pregnant female guinea-pigs. J Steroid Biochem 16: 107-116

Ballabio A, Carrozzo R, Parenti G, Gil A, Zollo M, Persico MG, Gillard E, Affara N, Yates J, Ferguson-Smith MA, Frants RR, Eriksson AW, Andria G (1989): Molecular heterogeneity of steroid sulfatase deficiency. Genomics $4: 36-40$

Basler E, Grompe M, Parenti G, Yates J, Ballabio A. (1992): Identification of point mutation in the steroid sulfatase gene of three patients with X-linked ichthyosis. Hun Genet 50: 483-491

Blin N, Stafford DW (1976): A general method for isolation of high molecular weight DNA from eukaryotes. Nucleic Acids Res 3: 2303

Chomeznski P, Sacchi N (1987): Single step method of RNA isolation by acid guanidinium thiocyanate-phenol-chloroform extraction. Anal Biochem 162: 156-159

Epstein EH, Leventhal ME (1981): Steroid sulfatase of human leukocytes and epidermis and the diagnosis of recessive X-linked ichthyosis. J Clin Invest 67: 1257-1262

Feinberg AP, Vogelstein B (1983): A technique for radiolabeling DNA restriction endonuclease fragments to high specific activity. Anal Biochem 132: 6-13 
Saiki RK, Gelfand DH, Stoffel S, Scharf SJ, Higuchi R, Horn GT, Mullis KB, Erlich HA (1988): Primer-directed enzymatic amplification of DNA with a thermostable DNA polymerase. Science 239: $487-489$

Sanger F, Nicklen S, Coulson AR (1977): DNA sequencing with chain-terminating inhibitors. Proc Natl Acad Sci USA 74: 5463-5467

Shapiro LJ (1989): Steroid sulfatase deficiency and X-linked ichthyosis. In: Scriver CR, Beauder A, Sly WS, Valle D (eds). The metabolic basis of inherited disease, 6th ed., McGraw-Hill, New York, pp. 1945-1964

Shapiro LJ, Yen P, Promerantz D, Martin E, Rolewic L, Mohandas T (1989): Molecular studies of deletions at the human steroid sulfatase locus. Proc Natl Acad Sci USA 86: 8477-8481

Warren JC, French AP (1965): Distribution of steroid sulfatase in human tissues. J Clin Endocrinol 25: $278-282$

Sugawara T, Gasa S, Honke K, Tanaka T, Fujimoto S (1991): Steroid sulfatase in gynecologic cancer-activity level and enzyme protein. Internal conference on placenta-Tokyo

Yen PH, Allen E, Marsh B, Mohandas T, Wang N, Taggart RT, Shapiro LJ (1987): Cloning and expression of steroid sulfatase cDNA and the frequent occurrence of deletions in STS deficiency: Implications for X-Y interchange. Cell 49:443-454

Yen PH, March B, Allen E, Tsai SP, Ellison J, Connolly L, Neisuwanger K, Shapiro LJ (1988): The human X-linked steroid sulfatase gene and a $Y$-encoded pseudogene: evidence for an inversion of the $\mathrm{X}$ chromosome during primate evolution. Cell 55: 1123-1135 